\title{
Erratum to: Environment-Assisted Cracking of Twinning Induced Plasticity (TWIP) Steel: Role of pH and Twinning
}

\author{
R.K. SINGH RAMAN, MUHAMMED KHALISSI, and SHAHIN KHODDAM
}

DOI: $10.1007 / \mathrm{s} 11661-017-4329-\mathrm{x}$

(C) The Minerals, Metals \& Materials Society and ASM International 2017

Erratum to: Metallurgical and Materials Transactions A, Volume 45A, April 2014, pp. 1979-95

DOI: 10.1007/s11661-013-2142-8

DUE to an error by the authors, Reference 3, R.K. Singh Raman, M. Khalissi, and S. Khoddam: Scripta Mater., 2012, vol. 67, p. 943 should have been cited as a source of some of the data for Figures 3, 4, 8, and 9.

R.K. SINGH RAMAN, Professor, is with the Department of Mechanical \& Aerospace Engineering, Monash University, Melbourne, VIC 3800, Australia, and also with the Department of Chemical Engineering, Monash University. Contact e-mail: raman.singh $@$ monash.edu MUHAMMED KHALISSI, formerly Ph.D. Student, and SHAHIN KHODDAM, formerly Senior Lecturer, are with the Department of Mechanical \& Aerospace Engineering, Monash University are now Independent Researchers.

The online version of the original article can be found under doi: 10.1007/s11661-013-2142-8.

Article published online September 14, 2017 